УКДН 13.040.50

НОРМУВАННЯ ТВЕРДИХ ЧАСТИНОК У ВИКИДАХ ЗАБРУДНЮЮЧИХ РЕЧОВИН 3 ВІДПРАЦЬОВАНИМИ ГАЗАМИ ТЕПЛОВОЗНИХ ДИЗЕЛІВ

Кандидати техн. наук А.О. Каграманян, В.В. Захарченко

НОРМИРОВАНИЕ ТВЕРДЫХ ЧАСТИЦ В ВЫБРОСАХ ЗАГРЯЗНЯЮЩИХ ВЕЩЕСТВ С ОТРАБОТАННЫМИ ГАЗАМИ ТЕПЛОВОЗНЫХ ДИЗЕЛЕЙ

Кандидаты техн. наук А.А. Каграманян, В.В. Захарченко

\title{
CHANGES TO GATS 32.001-94 VIBROSY POLLUTANTS FROM EXHAUST GASES OF DIESEL ENGINES
}

Candidate of techn. sciences A. Kagramanian, V. Zakharchenko

Установлено необхідність та внесені зміни до діючого стандарту ГСТУ 32.001-94 «Викиди забруднюючих речовин з відпрацьованими газами тепловозних дизелів. Норми та методи визначення» у відповідності до вимог стандартів, щ⿻о діють у крайнах $Є C$.

Ключові слова: викид, відпрачьовані гази, норматив вмісту забруднюючої речовини, ваговий коефіиієнт, ијик випробувань. 
Установлена необходимость и внесены изменения в действующий стандарт ГСТУ 32.001-94 «Выбросы загрязняющих веществ с отработавшими газами тепловозных дизелей. Нормы и методы определения» в соответствии с требованиями стандартов, действующих в странах ЕC.

Ключевые слова: выброс, отработанные газы, норматив содержания загрязняющего вещества, весовой коэффициент, ияикл испытаний.

Established the need and amendments to existing standards GATS 32.001-94 "Emissions of pollutants from exhaust gases diesels. Norms and methods of determination." In compliance with the standards in force in the $E U$.

Keywords: emissions, waste gases, pollutant standard content, weight, cycle tests.

Вступ. Тепловозний парк України $є$ досить великим споживачем природних ресурсів i джерелом забруднення навколишнього середовища. Економічні та соціальні збитки від викидів забруднюючих речовин підприємствами залізничного транспорту пов'язані з тим, що унаслідок цього знижується продуктивність праці робітників, поширюються захворювання як працівників підприємств, так і мешканців районів, де розташовані підприємства, а це у свою чергу призводить до додаткових витрат на медичне обслуговування. Викиди забруднюючих речовин негативно впливають на довговічність машин, обладнання, рухомого складу, будинків і споруд.

Значний збиток навколишньому середовищу наносять забруднюючі речовини, що входять до складу відпрацьованих газів дизелів тепловозів. Потрапляючи спочатку в атмосферу, вони негативно впливають не тільки на організми людей й тварин, але й на рослинність, грунт, воду, будинки й споруди.

Аналіз існуючої закордонної та вітчизняної нормативної бази, яка стосується нормування забруднюючих речовин від дизелів тепловозів, показав, що діючий Галузевий стандарт ГСТУ 32.001-94 «Викиди забруднюючих речовин 3 відпрацьованими газами тепловозних дизелів. Норми та методи визначення» [1] (Наказ Міністерства транспорту України від 1994-10-06 № 521) необхідно корегувати шляхом внесення до нього змін у частини нормування у викидах тепловозних дизелів середньоексплуатаційного питомого викиду твердих частинок.

Постановка проблеми у загальному вигляді та її зв'язок із важливими науковими та практичними завданнями. Тверді частинки, що містяться у відпрацьованих газах дизелів, виникають 3 різних причин і можуть мати різний склад. До твердих частинок раніше відносили сажу, яка являє собою тверді вуглеводні, що утворюються при частковому згорянні палива або термічному розкладанні вуглеводнів. Тому концентрацію твердих частинок у відпрацьованих газах однозначно зв'язували 3 димністю, яку визначають за оптичною щільністю відпрацьованих газів. З'явилися навіть емпіричні залежності, що зв'язують концентрацію сажі у відпрацьованих газах 3 димністю. У теперішній час до твердих частинок відносять усі субстанції, які перебувають у суміші відпрацьованих газів, із чистим повітрям при максимальній температурі $52{ }^{\circ} \mathrm{C}$, затримуються фільтром зі скловолокна 3 тефлоновим покриттям і не $\epsilon$ рідиною [2].

Тверді частинки діляться на розчинні й нерозчинні. Розчинні тверді частинки - це адсорбовані вуглеводні, що виділяються 3 палива або мастил. Ці частинки можуть бути затримані фільтром при їхній конденсації або абсорбцією при відповідних температурах. Нерозчинні тверді частинки складаються із сажі, золи, пилу, а також оксидів металів, що додають до палива та мастила як присадки, i абразивних частинок (продуктів зносу деталей). Як показали дослідження, на сажу припадає близько $50 \%$ частинок, а на вуглеводні близько $40 \%$ [2].

Тверді частинки мають велику сумарну поверхню, адсорбують інші речовини, що містяться у відпрацьованих газах, i можуть бути каталізаторами підвищення активності інших речовин. Разом 3 твердими частинками інші речовини набувають високої біологічної і хімічної активності, нових властивостей, у тому числі і небезпечних. Тверді частинки вражають легені людини, при розмірах до 1 мкм проникають глибоко в легені і не видаляються. Перебуваючи в атмосфері, вони знижують сонячне освітлення і видимість, підвищують хмарність і туманність, підвищують кількість опадів, руйнують і забруднюють матеріали, 
підвищують швидкість хімічних та фотохімічних реакцій в атмосфері, впливають на грунти та рослинність $[3,4]$.

Таким чином, у нормативних документах, спрямованих на захист навколишнього природного середовища від забруднюючих речовин у відпрацьованих газах дизелів, у першу чергу треба особливу увагу приділяти саме тим речовинам із зазначених, які $\epsilon$ найбільш небезпечними.

Аналіз останніх досліджень i публікацій. В Україні, як і у більшості розвинених країн, створена нормативна база 3 питань природоохоронної діяльності. Державне регулювання у сфері захисту навколишнього природного середовища, зокрема атмосферного повітря, базується на встановлених технічних нормативах забруднення та гранично допустимих викидів.

Як відомо, одним 3 основних джерел забруднення атмосферного повітря на залізничному транспорті $\epsilon$ його тяговий рухомий склад, зокрема тепловози та дизельпоїзди. Як показав аналіз останніх досліджень та публікацій в розвинутих країнах обов'язковим показником нормування викидів забруднюючих речовин від тепловозних дизелів $\epsilon$ тверді частинки [2]. Це забруднення передбачається у вимогах відповідно до ЄВРО V [5].

Визначення мети та задачі дослідження. Основні положення вітчизняних нормативних документів поширюються на всі джерела забруднення навколишнього природного середовища, зокрема на пересувні джерела, до яких відносяться тепловози. Але нормативи вмісту забруднюючих речовин у відпрацьованих газах повинні встановлюватись для кожного типу пересувних джерел [6-8] 3 урахуванням виду палива та особливостей даного джерела, які впливають на викиди. Для тепловозів, як пересувних джерел забруднення, можна відмітити дві особливості. По-перше, на тепловозах установлюють потужні дизелі, двигунів такої потужності немає на інших наземних транспортних засобах. По-друге, режими роботи дизелів тепловозів суттєво відрізняються від режимів роботи двигунів інших наземних транспортних засобів. Тому розроблені для інших пересувних джерел, наприклад для двигунів автомобільного транспорту, нормативи вмісту забруднюючих речовин у відпрацьованих газах не можуть бути поширені на дизелі тепловозів. Тобто для нормування викидів забруднюючих речовин у відпрацьованих газах дизелів тепловозів повинні бути окремі нормативні документи.

Основна частина дослідження. Нормування викидів забруднюючих речовин у відпрацьованих газах дизелів тепловозів здійснюється зараз за ГСТУ 32.001-94. Цей стандарт введений у дію з 1995 року, за минулий час у нього не вносились зміни або доповнення. Разом з тим після його введення в дію було прийнято нові державні стандарти щодо захисту навколишнього природного середовища або змінені та доповнені існуючі. Прийнято також низку інших нормативних документів 3 цього ж питання. 3'явились нові міжнародні зобов'язання України з обмеження викидів забруднюючих речовин. У розвинених країнах світу, зокрема в європейських країнах i в $\mathrm{EC} \mathrm{взагалі,} \mathrm{обмеження} \mathrm{викидів}$ забруднюючих речовин стає все більш жорстким. Тому Україна змушена підтягуватись до вимог Європейського Союзу щодо викидів забруднюючих речовин у відпрацьованих газах дизелів.

Крім того, за діючим ГСТУ 32.001-94 нормуються викиди оксидів азоту, оксидів вуглецю та вуглеводнів. Сьогодні вказаних трьох складових забруднюючих речовин уже недостатньо. Вважають, що коло складових треба розширювати, зокрема, необхідно нормувати викиди твердих частинок. У цьому напрямку просувається робота 3 нормування викидів для різних пересувних джерел забруднення, у тому числі для дизелів тепловозів. Україна у цих питаннях не має права відставати від європейських країн.

Згідно 3 нормативним документом «Порядок розроблення та затвердження нормативів вмісту забруднюючих речовин у відпрацьованих газах та впливу фізичних факторів пересувних джерел забруднення атмосферного повітря» підставами для перегляду нормативів $\epsilon$ :

- наявність можливостей щодо зменшення вмісту забруднюючих речовин у відпрацьованих газах пересувних джерел забруднення атмосферного повітря і відповідні технічні рішення;

- зміни у національному законодавстві та законодавстві Європейського Союзу щодо обмеження вмісту забруднюючих речовин у відпрацьованих газах пересувних джерел забруднення атмосферного повітря. 
До цього слід додати, що з часу введення в дію ГСТУ 32.001-94 накопичився досвід визначення фактичних викидів забруднюючих речовин у відпрацьованих газах дизелів тепловозів, що перебувають в експлуатації. Цей досвід може бути використаний для наближення вимог зазначеного стандарту до сучасних.

Крім того, з'явились нові технічні можливості для вимірювання викидів забруднюючих речовин, зокрема для вимірювання викидів твердих частинок.

3 урахуванням наведених зауважень нами було розроблено i внесено до діючого ГСТУ 32.001-94 «Викиди забруднюючих речовин з відпрацьованими газами тепловозних дизелів. Норми та методи визначення» зміни.

Для відповідності стандарту європейським вимогам був введений показник середньоексплуатаційний питомий викид твердих частинок $-E_{T \varphi}$.

Для його визначення були введені такі величини: натуральний показник ослаблення світлового потоку $K$; коефіцієнт ослаблення світлового потоку $N$;димове число фільтра $F S N$; питомий викид твердих частинок $e_{T ч}$.

Викиди твердих частинок $C_{T \varphi}$ вимірюють прийнятою в європейських країнах «Системою визначення вмісту твердих частинок у відпрацьованих газах». Допускається визначати викиди твердих частинок шляхом вимірювання димності відпрацьованих газів 3 подальшим переведенням показника димності у викиди на основі встановлених взаємозв'язків між ними та перерахунком на середньоексплуатаційні питомі викиди.

Нами запропоновано, що вимірювання димності відпрацьованих газів допускається проводити одним $з$ таких методів:

- оптичним методом 3 вимірюванням натурального показника $K$ ослаблення світлового потоку і коефіцієнта $N$ ослаблення світлового потоку;

- фільтраційним методом з вимірюванням димового числа FSN фільтра.

Визначені показники димності перевіряють на відповідність стандартним умовам за допомогою коефіцієнта атмосферних умов $F$, який обчислюють за формулою

$$
F=\left(\frac{t_{a}+273}{293}\right)^{0,5} \times\left(\frac{101}{p_{a}}\right)^{0,65}
$$

де $t_{a}$ - температура атмосферного повітря під час проведення випробування, ${ }^{0} \mathrm{C}$;

$p_{a}$ - атмосферний тиск під час проведення випробування, кПа.

Результати випробувань не потребують корегувань, якщо коефіцієнт $F$ у межах від 0,98 до 1,02 . Якщо значення коефіціснта $F$ виходить за вказані межі, то отримані значення показників димності слід корегувати за методикою виробника димоміра.

Величини викидів твердих частинок $C_{T Y}$ у залежності від коефіцієнта $N$ ослаблення світлового потоку визначають за рис. 1.

Величини натурального показника ослаблення світлового потоку $K$ у залежності від коефіцієнта ослаблення світлового потоку $N$ визначають за рис. 2.

Питомий викид твердих частинок $e_{T \Psi}$, г/(кВт·год), на кожному режимі роботи дизеля обчислюють за формулою:

$$
e_{T \varphi}=\frac{3600 C_{T \Psi} V_{2}}{P_{e}} .
$$

Висновки 3 дослідження і перспективи, подальший розвиток у даному напрямку. Проведене дослідження дало змогу отримати теоретичні залежності та методичні вимоги й рекомендації щодо змін стосовно проведення вимірювань наявності та кількісного вмісту твердих частинок у відпрацьованих газах тепловозних дизелів. Відмічені результати було впроваджено у вигляді зміни до діючого ГСТУ 32.001-94 і затверджено Міністерством інфраструктури України від 25.05.2015 p. № 179. Запропоновані зміни у складі ГСТУ 32.001-94 запроваджені для покращення рівня екологічних випробувань тепловозних дизелів на підприємствах Укрзалізниці та підпорядкованих Міністерству інфраструктури України. У подальшому отримані матеріали можуть бути використані при розробленні нових або перегляді існуючих нормативних документів 3 питань екологічної безпеки транспортних засобів. 


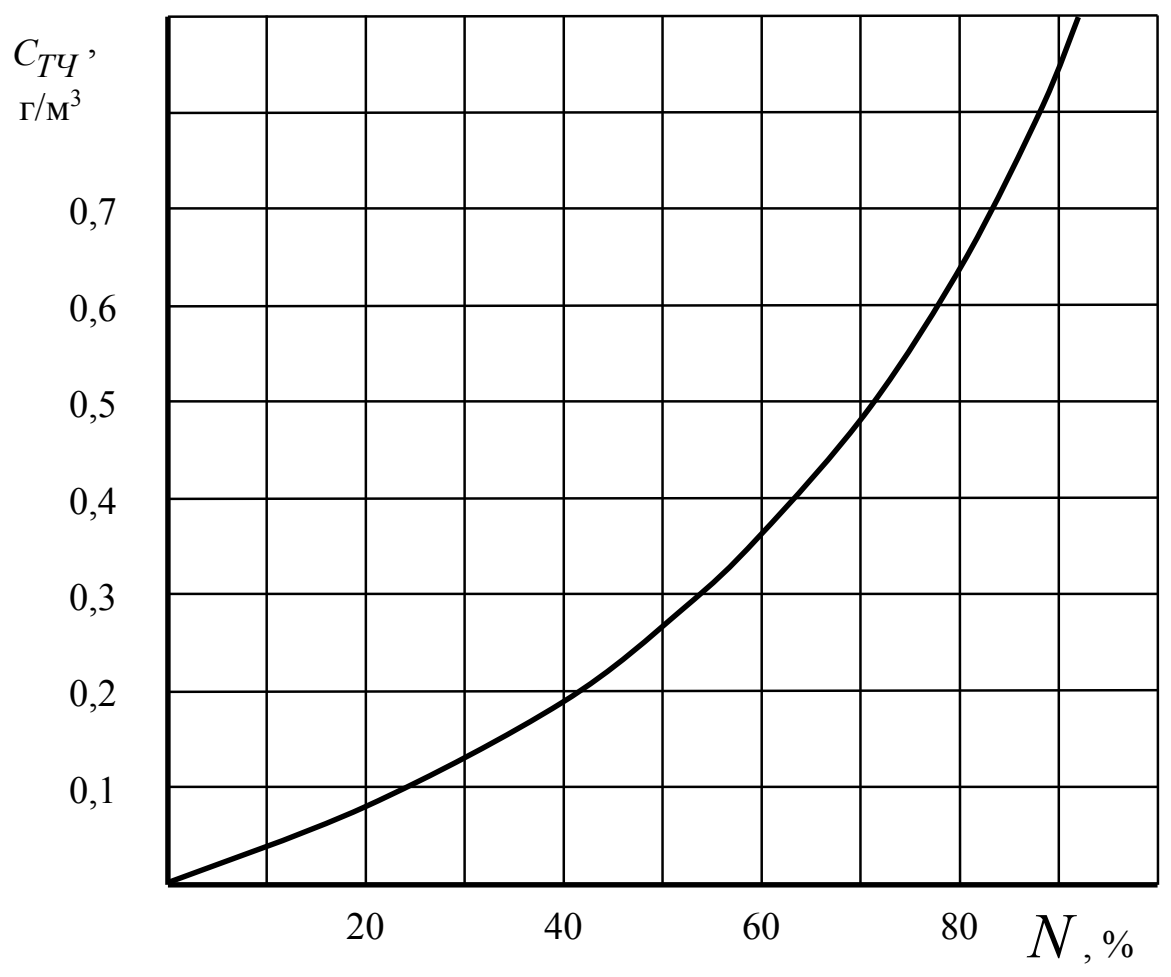

Рис. 1. Залежність викидів твердих частинок $C_{T \Psi}$ від коефіцієнта ослаблення світлового потоку $N$

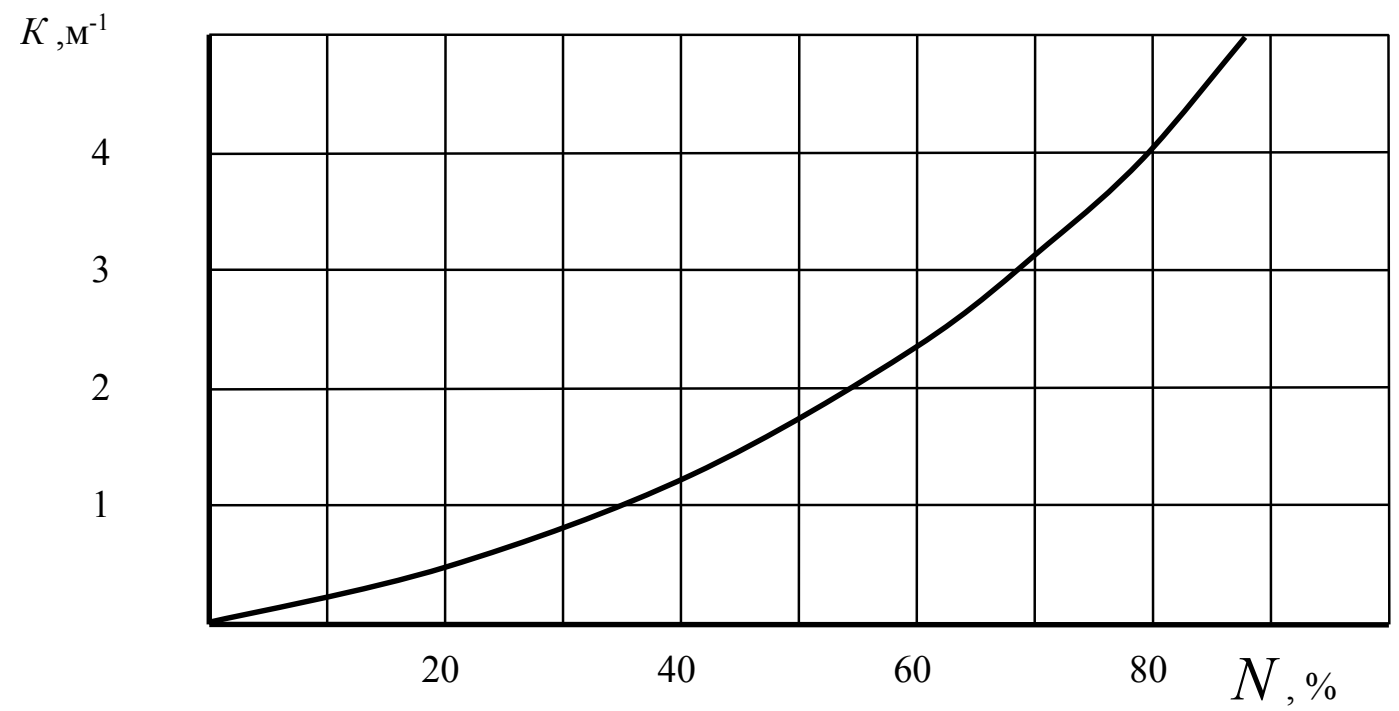

Рис. 2. Залежність натурального показника ослаблення світлового потоку $K$ від коефіцієнта ослаблення світлового потоку $N$ 


\section{Список використаних джерел}

1. ГСТУ 32.001-94. Выбросы загрязняющих веществ с отработавшими газами тепловозных дизелей. Нормы и методы определения [Текст]. - К.: Министерство транспорта Украины, 1994. - 12 с.

2. Каграманян, А.О. Нормування викидів забруднюючих речовин від тепловозних двигунів [Текст] / А.О. Каграманян, А.В. Онищенко, П.В. Рукавишников // Зб. наук. праць ДонІЗТ. - Донецьк, 2008. - № 16. - С. 94-106.

3. Захист навколишнього середовища при роботі теплотехнологічного устаткування [Текст]: навч. посібник / Н.А. Шаройко, А.О. Каграманян, І.П. Полтавський, В.В. Савенко. - Харків: УкрДАЗТ, 2011. - 400 с.

4. Про охорону атмосферного повітря: закон України [Електронний ресурс]. - Режим доступу: http://ecopravo.org.ua/2010/03/15/zakon-ukrani-pro-oxoronu-atmosfernogo-povtrja/ .

5. Каграманян, А.О. Дослідження впливу основних факторів експлуатації дизелів тепловозів на викиди забруднюючих речовин [Текст] / А.О. Каграманян, П.В. Рукавишников // Зб. наук. праць ДонІЗТ. Донецьк, 2010. - № 21. - С. 160-170.

6. ГОСТ Р 50953-96. Выбросы вредных веществ и дымность отработавших газов магистральных и маневровых тепловозов. Нормы и методы определения [Текст]. - М.: Госстандарт России, 1996. $-16 \mathrm{c}$.

7. ГОСТ Р 50953-2008 Выбросы вредных веществ и дымность отработавших газов магистральных и маневровых тепловозов. Нормы и методы определения. [Электронный ресурс]. Режим доступа: - http://www.opengost.ru//3791-gost-r-50953-2008-vybrosy-vrednyh-veschestv-i-dymnostotrabotavshih-gazov-magistralnyh-i-manevrovyh-teplovozov.-normy-i-metody-opredeleniya.html .

8. Каграманян, А.О. Визначення параметрів тепловозного дизеля $5 Д 49$ при його роботі 3 різними варіантами суміші дизельного палива та метилового ефіру ріпакової олії [Текст] / А.О. Каграманян, О.Г. Крушедольский, В.В. Захарченко // Зб. наук. праць. - Харків: УкрДАЗТ, 2013. - № 141. - C. 137-154.

Рецензент д-р техн. наук, професор А.П. Фалендиш

Каграманян Артур Олександрович, канд. техн. наук, доцент, кафедра теплотехніки та теплових двигунів, Український державний університет залізничного транспорту. Тел.: (057) 730-10-07. E-mail: kartal2@ukr.net.

Захарченко Вячеслав Вікторович, канд. техн. наук, доцент, кафедра механіки та проектування машин, Український державний університет залізничного транспорту. Тел.: (057) 730-10-07. E-mail: vz304@ukr.net.

Kagramanian Artur, cand. of techn. sciences, associate professor, department teplotehnyka and heat engines, Ukrainian State University of Railway Transport. Tel.: (057) 730-10-07. E-mail: kartal2@ukr.net.

Zakharchenko Vyacheslav, cand. of techn. sciences, associate professor, department of mechanics and machine design, Ukrainian State University of Railway Transport. Tel .: (057) 730-10-07. E-mail: vz304@ukr.net.

Наукова праця здана до друку 05.10.2015 p. 